\title{
WORKSHOP PERHITUNGAN, PEMOTONGAN, PEMUNGUTAN DAN PELAPORAN PAJAK PPH PASAL 21 DAN 23 UNTUK APARATUR DESA (PADA 20 DESA DI KECAMATAN KARANGPAWITAN KABUPATEN GARUT)
}

\author{
Sri Rahayu' ${ }^{1}$, Kurnia ${ }^{1}$, Vaya J. Dillak ${ }^{1}$ Nugraha M.R. Shodiq $^{1}$ \\ ${ }^{1}$ Jurusan S1 Akuntansi, Universitas Telkom Bandung \\ Email:srirahayunchi@gmail.com
}

\begin{abstract}
ABSTRAK,
Sesuai dengan PP 47 tahun 2015 dan PP 43 tahun 2014 tentang Desa dan merujuk pada pasal 81 mengenai penghasilan tetap aparat desa dimana penghasilan tetap kepala desa dan perangkat desa dianggarkan dalam $A P B$ Desa yang bersumber dari ADD, serta pengalokasian ADD untuk penghasilan tetap kepala desa dan perangkat desa menggunakan perhitungan tertentu. Jumlah nilai yang dicatat adalah sebesar jumlah pajak yang dipungutnya yang dihitung dari nilai transaksi. Untuk penyetoran pajak ke kas negara dicatat sebesar nilai surat setoran pajak (SSP) yang dibuatnya. Dalam hal pelaksanaan kegiatan-kegiatan di atas yang terkait dengan perpajakan memerlukan pengetahuan sesuai dengan undang-undang yang berlaku, mengingat adanya permintaan dari kecamatan yang telah melalukan kerjasama sebagai mitra dan belum meratanya aparatur desa yang dilihat dari pengetahuan dan juga pendidikan maka para desa memerlukan pengetahuan dalam pengelolaan pajak tersebut. Pada program pengabdian ini diberikan pelatihan bagi para bendahara dan Sekretaris Desa tentang perhitungan, pemotongan, pemungutan dan pelaporan pajak khususnya PPh pasal 21 dan 23. Sebagai luaran dari program pengabdian ini adalah para pengurus desa dapat memahami pengelolaan serta pertanggungjawaban berkenaan dengan pajak pada desanya masing-masing. Dari hasil kuesioner kepuasan atas pelaksanaan terlihat program ini sangat bermanfaat, dan dari hasil uji beda menggambarkan perbedaan antara pengetahuan dan pemahaman sebelum dan setelah pelatihan. Kegiatan pengabdian ini diharapkan dapat berkelanjutan sebagai bentuk tridharma perguruan tinggi.
\end{abstract}

Kata kunci: pemahaman, desa, pajak, pph pasal 21, pasal 23

\section{PENDAHULUAN}

PPh pasal 21 adalah pemotongan pajak yang dilakukan oleh pihak pemberi penghasilan kepada oleh wajib pajak orang pribadi dalam negeri sehubungan dengan pekerjaan atau kegiatan yang dilakukan, sedangkan PPh pasal 23 adalah pemotongan pajak yang dilakukan oleh pihak pemberi penghasilan sehubungan dengan pembayaran berupa deviden, bunga, royalty, sewa, dan jasa kepada WP badan dalam negeri dan BUT (Diana, 2013: 217). Contohnya adalah pemotongan dan penghitungan $\mathrm{PPh}$ pasal 23 atas jasa tertentu (jasa service mesin atau komputer) yang pemotongannya dilakukan oleh Wajib Pajak berbentuk badan.

Pembukuan adalah suatu proses pencatatan yang dilakukan secara teratur untuk mengumpulkan data dan informasi keuangan yang meliputi harta, kewajiban, modal, penghasilan dan biaya, serta jumlah harga perolehan dan penyerahan barang atau jasa, yang ditutup dengan menyusun laporan keuangan untuk periode tahun pajak tersebut (Diana, 2013 : 222). Bendahara Desa sebagai wajib pungut pajak penghasilan $(\mathrm{PPh})$ dan pajak lainnya, wajib menyetorkan seluruh penerimaan potongan dan pajak yang dipungutnya ke rekening kas negara sesuai dengan ketentuan peraturan perundang-undangan (Permendagri 113/2014, pasal 31). Kemudian Bendahara Desa mencatat pemotongan dan penyetoran pajak pada BKU dan buku pajak. Jumlah nilai yang dicatat adalah sebesar jumlah pajak yang dipungutnya yang dihitung dari 
nilai transaksi. Untuk penyetoran pajak ke kas negara dicatat sebesar nilai surat setoran pajak (SSP) yang dibuatnya. Terkait dengan penghasilan tetap aparat desa ini masih terjadi kekurang pahaman atas kegiatan-kegiatan yang berkenaan dengan pajak sehingga pada saat pelaporan sering terjadi kesalahan. Hal ini terjadi salah satunya gambaran Kepala Desa, Sekretaris Desa dan bendahara Desa di Indonesia yang diambil dari Kementrian Dalam Negeri dilihat dari segi pendidikan dominan masih disekitar tamatan SMA dan SMP, tergambar sebagai berikut :

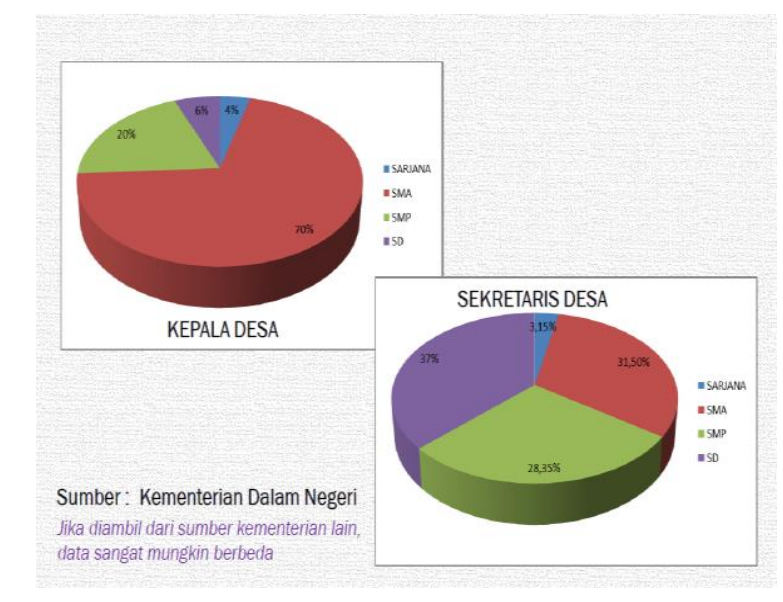

Gambar 1. Pendidikan Kepala Desa Dan Sekdes Di Indonesia

Gambaran di atas menunjukan bahwa pemerintahan di tingkat desa masih rendah maka SDM aparatur pemerintahan harus ditingkatkan, pembagian kerja belum sesuai SOTK, aparat pemerintah desa belum menguasai teknologi informasi, sulit melakukan reformasi birokrasi desa (hasil survei Desa Kertawangi Garut). Hal lain yang mendukung yaitu dari kajian yang dilakukan sejak ditandatanganinya surat kemitraan dengan Kecamatan Karangpawitan yang membawahi 20 Desa di wilayahnya memandang sangat perlu diadakannya edukasi mengenai perpajakan untuk para aparatur Desa khususnya dilingkungan kecamatan Karangpawitan ini sehingga akan meminimalisir kesalahan yang terkait dengan pajak serta meningkatkan pemahaman untuk aparatur Desa. Sebagai gambaran tingkat pendidikan aparatur desa terutama para Kades di lingkungan kecamatan Karangpawitan kabipaten Garut sebagai berikut:

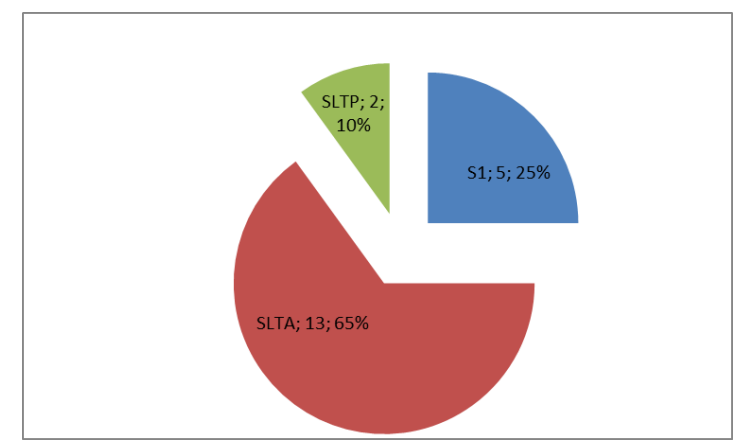

Gambar 2. Tingkat Pendidikan Kades di Lingkungan Kecamatan Karangpawitan

Berangkat dari fenomena di atas tim Pengabdian Masyarakat dari Program Studi S1 Akuntansi Fakultas Ekonomi dan Bisnis Universitas Telkom bermaksud mengadakan Workshop 
Perhitungan, Pemotongan, Pemungutan Dan Pelaporan Pajak PPh Pasal 21 dan 23 untuk Aparatur Desa (Pada 20 Desa di Kecamatan Karangpawitan kabupaten Garut).

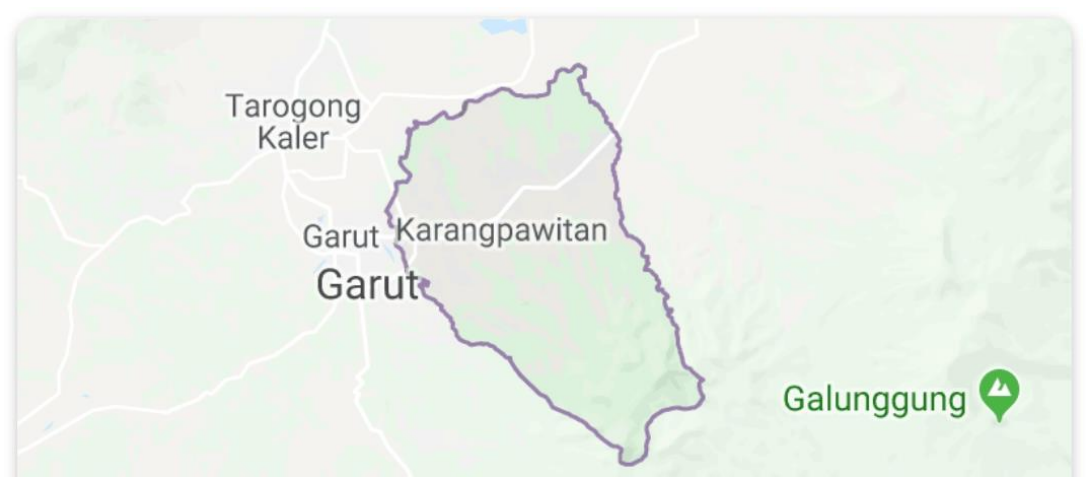

Gambar 3. Peta Lokasi Masyarakat Sasar

Gambaran peserta yang menjadi masyarakat sasar dalam program pengabdian terdiri dari Bendahara dan Sekretaris Desa dari 20 desa di lingkungan kecamatan Karangpawitan Garut.

Tabel 1. Daftar Kelurahan/Desa di Kecamatan Karangpawitan Kabupaten Garut

\begin{tabular}{|c|l|c|l|}
\hline No & \multicolumn{1}{|c|}{ Kelurahan/Desa } & No & \multicolumn{1}{|c|}{ Kelurahan/Desa } \\
\hline 1 & Cimurah & 11 & Sindanglaya \\
\hline 2 & Godog & 12 & Sindangpalay \\
\hline 3 & Jatisari & 13 & Situgede \\
\hline 4 & Karangmulya & 14 & Situjaya \\
\hline 5 & Karangpawitan & 15 & Situsaeur \\
\hline 6 & Karangsari & 16 & Situsari \\
\hline 7 & Lebakagung & 17 & Suci \\
\hline 8 & Lebakjaya & 18 & Sucikaler \\
\hline 9 & Mekarsari & 19 & Tanjungsari \\
\hline 10 & Sindanggalih & 20 & Lengkongjaya \\
\hline
\end{tabular}

\section{METODE PELAKSANAAN}

Implementasi dari kegiatan pelatihan Perhitungan, Pemotongan, Pemungutan Dan Pelaporan Pajak PPh Pasal 21 dan 23 bagi para Bendahara dan sekretaris desa dilaksanakan satu hari (full day workshop) dan sebelum melakukan pengabdian ini telah dilakukan penandatangan surat mitra sampai dengan tahun 2019 dan berkoordinasi dengan sekertaris camat Karangpawitan melalui WA yaitu waktu pelaksanaan workshop. Strategi pembelajaran yang digunakan adalah strategi pembelajaran kooperatif (SPK) merupakan strategi pembelajaran yang dirancang untuk mengembangkan kecakapan akademik (academic skill), keterampilan interpersonal, dan keterampilan sosial (social skill) (Dirman dan Cicih, 2014: 118). Prosedur yang dilakukan dalam kegiatan pengabdian kepada masyarakat dengan pembelajaran kooperatif (Sanjaya, 2008: 248) adalah dengan cara :

1. Penjelasan Materi, tahap penjelasan diartikan sebagai proses penyampaian pokok-pokok materi pembelajaran. Tujuan utama dalam tahap ini adalah pemahaman peserta terhadap pokok materi. Pada tahap ini digunakan metode ceramah, tanya jawab, dan demonstrasi. 
2. Penilaian, penilaian dalam strategi pembelajaran kooperatif dilakukan dengan tes atau kuis. Tes ini dilakukan secara individual, tes ini memberikan informasi kemampuan setiap peserta. Sebelum materi diberikan seluruh peserta diminta untuk mengisi pretest yang merupakan pertanyaan-pertayaan dasar mengenai $\mathrm{PPh}$ pasal 21, dan 23. Di akhir kegiatan kembali diberikan post test sebagai gambaran pemahaman. Untuk pengolahan dari pre dan post test ini digunakan uji beda.

3. Pengakuan, pengakuan (recognition) adalah penetapan peserta yang dianggap pling menonjol atau berprestasi untuk kemudian diberikan penghargaan atau hadiah. Pengakuan dan pemberian penghargaan tersebut diharapkan dapat memotivasi peserta lain untuk terus berprestasi dan juga membangkitkan peserta lain untuk lebih mampu meningkatkan prestasi mereka.

Materi yang diberikan saat pelaksanaan pengabdian masyarakat ini antara lain 1) Aspek perpajakan Desa dan istilah-istilah dalam perpajakan, 2) Perhitungan, pemotongan, pemungutan dan pelaporan pajak, 3) Bukti-bukti perpajakan Desa, 4) Pengarsipan dokumendokumen perpajakan.

Luaran yang diharapkan dari kegiatan pengabdian masyarakat ini adalah setiap desa sudah paham dan dapat melakukan kegiatan-kegiatan berkenaan dengan praktek pajak khususnya $\mathrm{PPh}$ pasal 21 dan 23, serta tertib dalam dokumentasinya sehingga berujung pada kesiapan pada saat dilakukannya audit atau pemeriksaan yang dilakukan oleh BPKP.

\section{HASIL DAN PEMBAHASAN}

Kegiatan pengabdian masyarakat ini diawali dengan pembukaan oleh Camat Karangpawitan serta ketua tim pengabdian dan dilanjutkan dengan kegiatan inti. Adapun dokumentasi atas pelaksanaannya sebagai berikut :

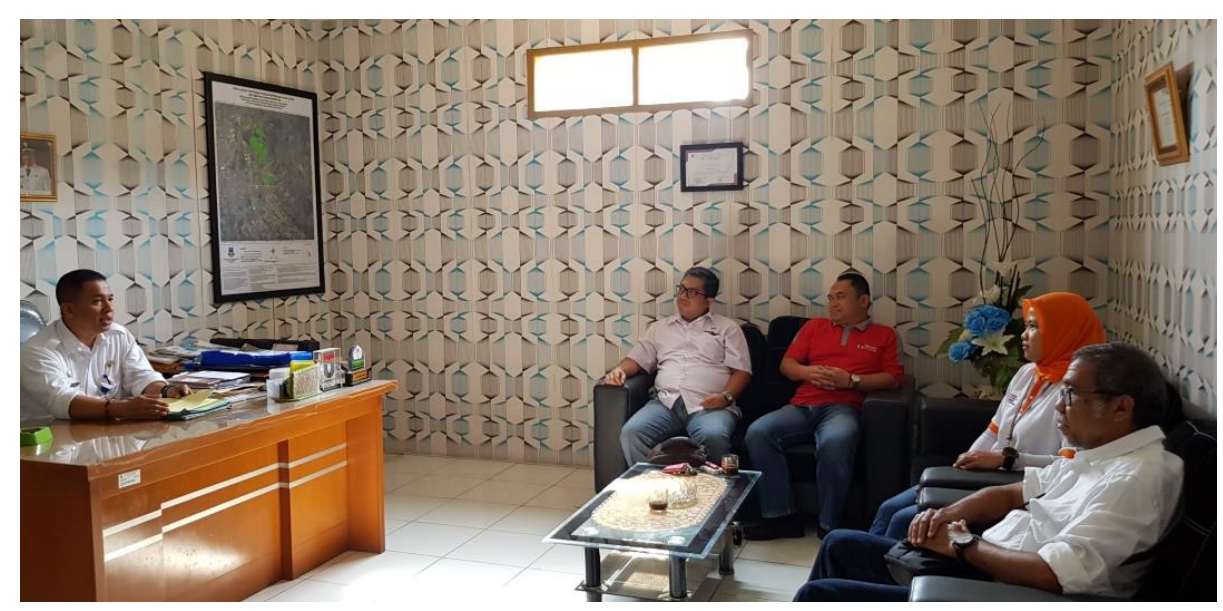

Gambar 4. Tim Berdiskusi dengan Camat Karangpawitan 
Bentuk penilaian atas pengetahuan para peserta, sebelum pelaksanaan pemberian materi diberikan pre test terlebih dahulu. Dan setelah pemberian materi diberikan post test.

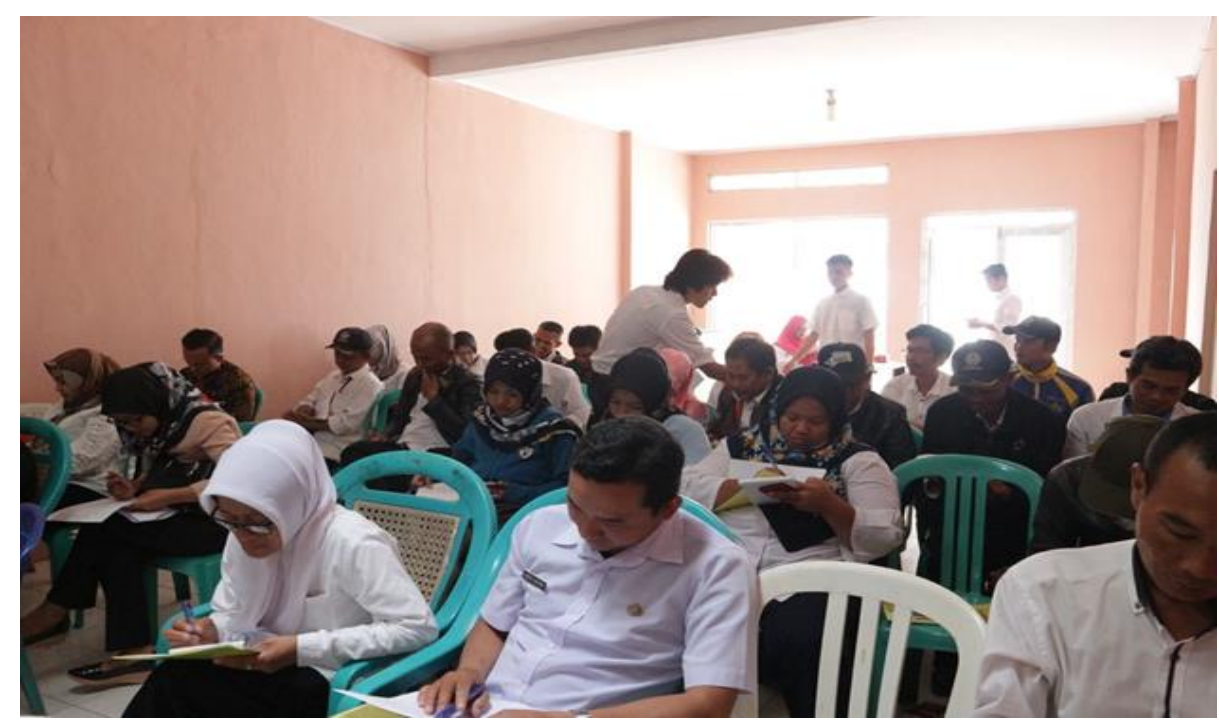

Gambar 5. Proses Pengisian Pre Test

Secara deskriptif akan dipaparkan gambaran hasil dari pengabdian beserta saran yang diperoleh dari hasil kuesioner kepuasan terhadap pelaksanaan kegiatan pengabdian masyarakat ini. Adapun pertanyaannya kepuasan ini meliputi :

1) Program pengabdian masyarakat ini sudah sesuai dengan tujuan kegiatan itu sendiri,

2) Program pengabdian kepada masyarakat ini sudah sesuai dengan kebutuhan masyarakat sasarnya,

3) Waktu pelaksanaan program pengabdian masyarakat ini relatif telah mencukupi sesuai kebutuhan,

4) Dosen dan mahasiswa Universitas Telkom bersikap ramah, cepat dan tanggap membantu selama kegiatan,

5) Masyarakat setempat menerima dan mengharapkan program pengabdian masyarakat Universitas Telkom saat ini dan masa yang akan datang.

Hasil dari pengolahan kuesioner atas pertanyaan-pertanyaan feedback yang diberikan oleh peserta terhadap tim dan pelaksanaan kegiatan pengabdian masyarakat ini tergambar sebagai berikut :

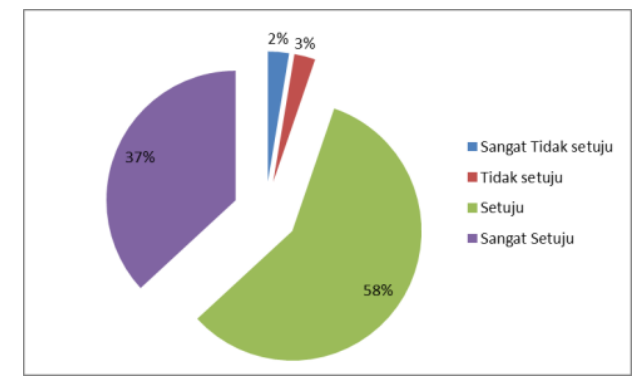

Gambar 6. Program Kegiatan Masysrakat

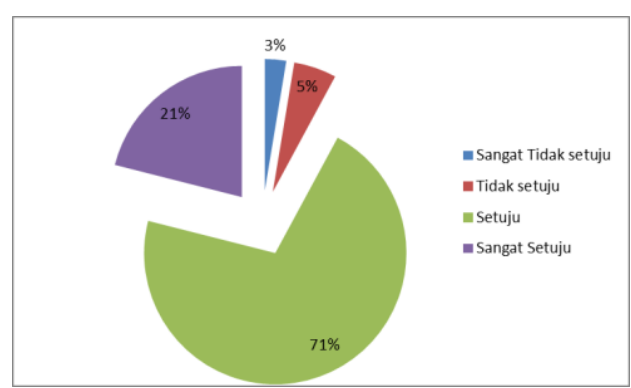

Gambar 7. Program pengabdian kepada 
Sudah sesuai dengan tujuan kegiatan

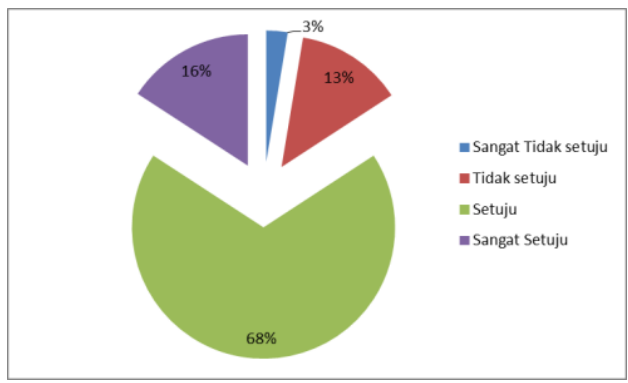

Gambar 8. Waktu pelaksanaan program pengabdian masyarakat ini relatif mencukupi sesuai kebutuhan masyarakat sudah sesuai dengan kebutuhan masyarakat sasarnya

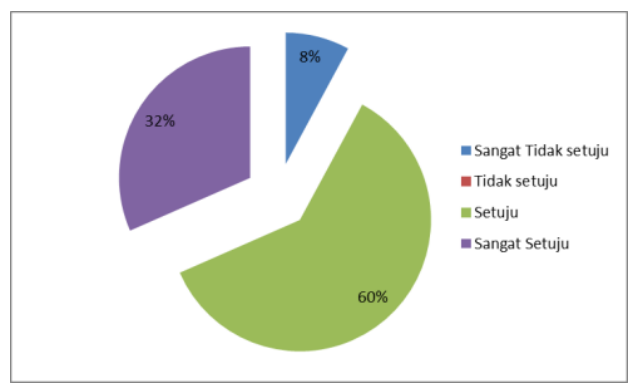

Gambar 9. Dosen dan mahasiswa Universitas Telkom bersikap ramah, cepat dan tanggap membantu selama kegiatan

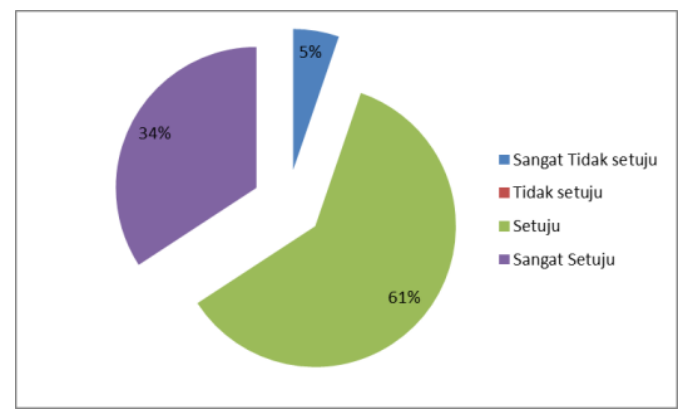

Gambar 10. Masyarakat setempat menerima dan mengharapkan program pengabdian masyarakat Universitas Telkom saat ini dan masa yang akan datang

Masing-masing gambar di atas menggambarkan hasil tanggapan masyarakat sasar atas pelaksanaan kegiatan pengabdian masyarakat. Secara tabulasi tergambar sebagai berikut :

Tabel 2. Hasil Tanggapan Masyarakat Sasar

\begin{tabular}{|c|c|c|c|c|}
\hline \multirow{2}{*}{ Penilaian Terhadap Kegiatan } & \multicolumn{4}{|c|}{$\begin{array}{c}\text { Jumlah Masing-masing Faktor yang } \\
\text { Dipertimbangkan }\end{array}$} \\
\hline & $\begin{array}{l}\text { Sangat Tdk } \\
\text { Setuju }\end{array}$ & $\begin{array}{l}\text { Tidak } \\
\text { Setuju }\end{array}$ & Setuju & $\begin{array}{l}\text { Sangat } \\
\text { Setuju }\end{array}$ \\
\hline $\begin{array}{l}\text { 1. Kegiatan ini sudah sesuai dengan tujuan kegiatan itu } \\
\text { sendiri }\end{array}$ & 1 & 1 & 22 & 14 \\
\hline $\begin{array}{l}\text { 2. Kegiatan ini sudah sesuai dengan kebutuhan } \\
\text { masyarakat sasarnya }\end{array}$ & 1 & 2 & 27 & 8 \\
\hline $\begin{array}{l}\text { 3. Waktu pelaksanaan kegiatan ini relatif telah } \\
\text { mencukupi sesuai kebutuhan }\end{array}$ & 1 & 5 & 26 & 6 \\
\hline $\begin{array}{l}\text { 4. Dosen dan mahasiswa Universitas Telkom bersikap } \\
\text { ramah, cepat dan tanggap membantu selama kegiatan }\end{array}$ & 3 & 0 & 23 & 12 \\
\hline $\begin{array}{l}\text { 5. Masyarakat setempat menerima dan mengharapkan } \\
\text { kegiatan Universitas Telkom saat ini dan masa yang } \\
\text { akan datang }\end{array}$ & 2 & 0 & 23 & 13 \\
\hline Jumlah & 8 & 8 & 121 & 53 \\
\hline$\%$ (jumlah masing-masing : total) & $4.2 \%$ & $4.2 \%$ & $63.68 \%$ & $27.89 \%$ \\
\hline Jumlah \% setuju + sangat setuju & \multicolumn{4}{|c|}{$91.57 \%$} \\
\hline
\end{tabular}

Dari rekapitulasi hasil feedback diperoleh nilai jumlah prosentase jawaban setuju dan jawaban sangat setuju atas pelaksanaan kegiat pengabdian masyarakat ini ada pada rentang "Sangat 
Baik" yaitu pada nilai 91.57\%. Semoga kegiatan Pengabdian Masyarakat ini dapat berjalan dalam jangka panjang, untuk mendukung pelaksanaan kegiatan Tridharma Perguruan Tinggi yang memberikan dampak baik bagi masyarakat.

Masukan-masukan terbuka yang dituliskan oleh masyarakat sasar secara tertulis disampaikan kepada tim dan selanjutnya dirangkum dengan hasil antara lain:

1) Materi yang disampaikan lebih spesifik dengan permasalahan yang ada di desa, terutama perhitungan dan klasifikasi pajak yang menyangkut desa,

2) Harap materinya dilanjut kembali sehingga materinya lebih banyak lagi yang tersampaikan,

3) Membuat blog khusus tanya jawab tentang pajak,

4) Durasi/waktu pelaksanaan ditambah,

5) Mohon program-program yang lainnya kami tunggu untuk membantu kami di desa,

6) Tolong dibantu aplikasi siskeudes,

7) Terimakasih dan lanjutkan.

Untuk melihat hasil peningkatan pemahaman atas materi yang diberikan, tim pengabdian memberikan pre test dan post test dengan hasil uji beda tergambar pada tabel berikut:

Tabel 3. Paired Samples Test

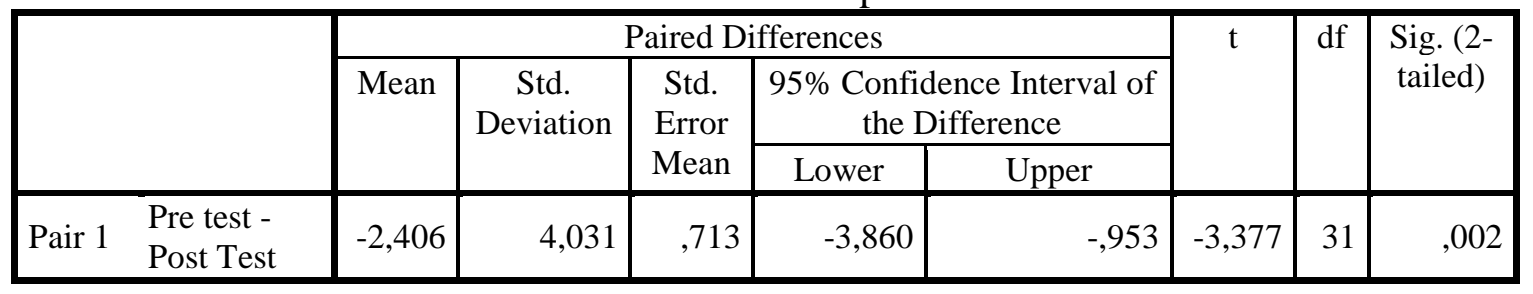

Dari hasil pengujian dapat dilihat dari tabel dengan nilai sig. (2 tailed) menunjukan hasil 0.002 yang berarti terdapat perbedaan tingkat pemahaman aparatur desa mengenai PPh pasal 21 dan 23 sebelum dan setelah program pengabdian masyarakat.

Setelah penyampaian materi selesai maka kepada seluruh peserta diberikan sertifikat sebagai peserta dan sebagai dokumentasi dilakukan foto bersama tim dengan seluruh peserta.
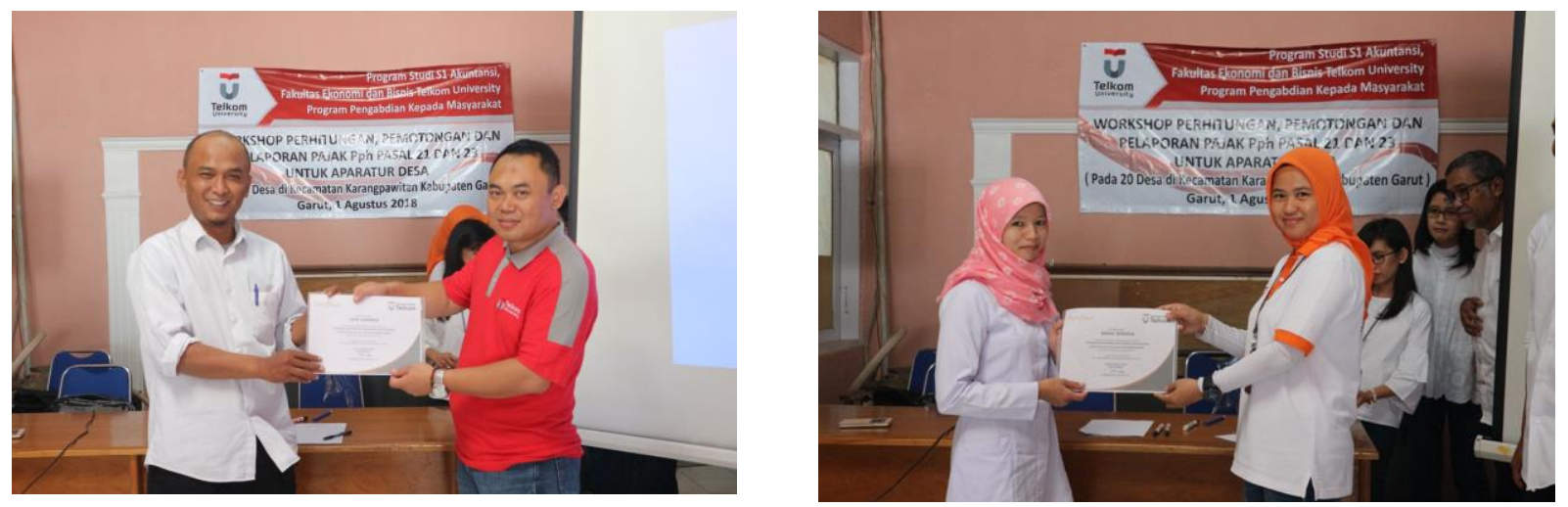

Gambar 11. Pemberian Sertifikat kepada Peserta 


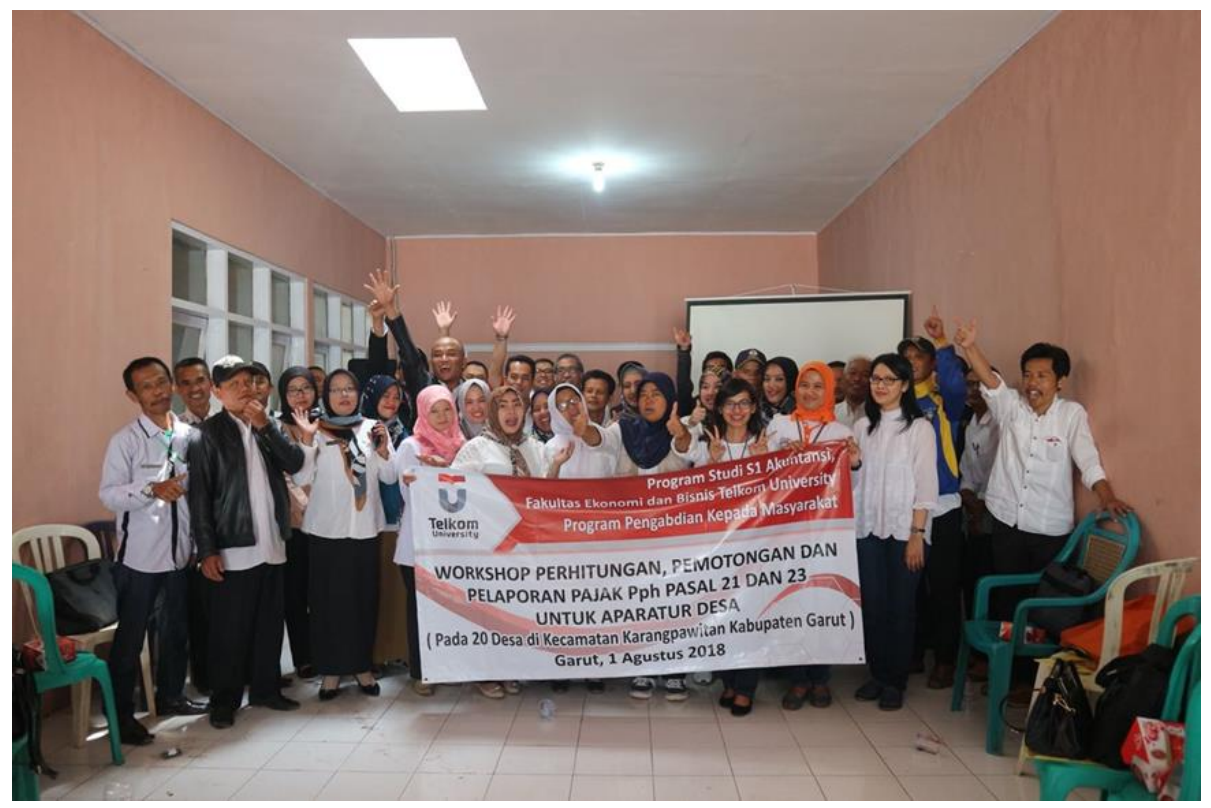

Gambar 12. Foto Bersama di Akhir Kegiatan PKM

\section{KESIMPULAN DAN SARAN}

Program pengabdian masyarakat ini sangat penting untuk dilakukan dengan tujuan untuk mengaplikasikan ilmu dan membantu pihak masyarakat sasar dalam memecahkan masalah untuk meningkatkan pengetahuan dan kualitasnya. Dari hasil pengabdian ini diperoleh gambaran dari tanggapan masyarakat sasar bahwa materi yang diberikan sesuai dengan kebutuhan masyarakat sasarnya, dari hasil uji beda terlihat adanya perbedaan tingkat pemahaman sebelum dan setelah mengikuti program ini. Adapun komentar yang tertulis diantaranya adalah masyarakat senantiasa menunggu program-program lainnya. Sebagai saran adalah pada saat sebelum melakukan selalu melakukan konfirmasi program atau materi yang paling dibutuhkan oleh masyarakat sasar.

\section{Acknowledgement}

Atas kegiatan pengabdian kepada masyarakat ini penulis sampaikan banyak terimakasih atas bantuan dan dukungan kepada Telkom University, Camat Karangpawitan Kabupaten Garut Rena Sudrajat, S.Sos., MM., aparatur desa di wilayah Karangpawitan atas semangat dan antusisnya mengikuti program ini, tim PKM serta mahasiswa sebagai asisten pelaksana PKM, dari persiapan, pelaksaaan, hingga terbitnya tulisan ini.

\section{REFERENSI}

Dirman. Juarsih, Cicih. (2014). Teori Belajar dan Prinsip-prinsip Pembelajaran yang Mendidik. PT Rineka Cipta, Jakarta.

https://www.kemendagri.go.id/arsip/categories/OTY/data-pokok. Diunduh tahun 2016.

https://peraturan.bkpm.go.id/jdih/userfiles/batang/PP\%2047\%202015\%20Perubahan\%20PP\% 2043\%202014\%20tentang\%20Peraturan\%20Pelaksanaan\%20UU\%206\%202014\%20te ntang\%20Desa.pdf . Diunduh tahun 2018.

https://www.kemenkopmk.go.id/sites/default/files/produkhukum/PP\%20Nomor\%2043\%20Ta hun\%202014.pdf. Diunduh tahun 2018. 
http://www.keuangandesa.com/wp-content/uploads/2015/04/Permendagri-No-113-Tahun2014-Tentang-Pengelolaan-Keuangan-Desa.pdf. Diunduh tahun 2018

Sanjaya, Wina. (2008). Strategi Pembelajaran Berorientasi Standar Proses Pendidikan. Kencana, Jakarta.

Sari, Diana. (2013). Konsep Dasar Perpajakan. PT Refika Aditama, Bandung. 